\title{
Granulomatosis with polyangiitis (Wegener's granulomatosis) with hard palate and bronchial perforations treated with rituximab - a case report
}

\section{Opis przypadku pacjenta z perforacją podniebienia twardego i oskrzeli w przebiegu ziarniniakowatości z zapaleniem naczyń (ziarniniaka Wegenera) leczonego rituximabem}

The authors declare no financial disclosure

\section{Abstract}

We present a case of a 57-year-old woman suffering from granulomatosis with polyangiitis (GPA), who in the seventh months of immunosuppressive treatment (cyclophosphamide) progressed with new pulmonary changes and perforations of the hard palate and bronchi. Rituximab was introduced resulting in B-cell depletion and disappearance of anti-PR3 antibody. Palatal holes have substantially diminished and all bronchial perforations disappeared, covered by fibrous tissue. In the fourth month after rituximab administration, large scarring obstruction of the right main bronchus with upper and middle lobes atelectasis emerged. Because of increasing dyspnoea, stenotic bronchus was re-opened by bronchoscopy. Intervention was complicated by bilateral pneumothorax and later, on the seventh day, by fatal pulmonary bleeding. To our knowledge, this is the first report of GPA refractory to cyclophosphamide complicated by palatal and bronchial perforations.

Key words: rituximab, granulomatosis with polyangiitis, vasculitis, Wegener's granulomatosis, immunosuppression, palatal perforation, bronchial perforation

Pneumonol. Alergol. Pol. 2014; 82: 454-457

\section{Streszczenie}

Przedstawiamy przypadek 57-letniej pacjentki z ziarniniakowatością z zapaleniem naczyń (GPA), u której pomimo trwającej siedem miesięcy terapii immunosupresyjnej (cyklofosfamidem) doszło do progresji choroby podstawowej. Z uwagi na to, że u chorej stwierdzono nowe zmiany w płucach oraz perforacje oskrzeli i podniebienia twardego, włączono rituximab, co doprowadzito do zmniejszenia ilości limfocytów B we krwi obwodowej oraz do zaniknięcia przeciwciał anty-PR3. Perforacje podniebienia uległy znacznemu zmniejszeniu, natomiast perforacje oskrzeli zanikły i zostały pokryte przez tkankę włóknistą. Po czterech miesiącach od rozpoczęcia leczenia rituximabem uwidoczniono niedodmę płatów górnego i środkowego prawego wynikającą z niedrożności oskrzela głównego prawego (wtórnie do procesu bliznowacenia). Z uwagi na narastającą niewydolność oddechową wykonano zabieg poszerzenia oskrzela, powikłany obustronną odmą, a następnie, siódmego dnia po zabiegu, doszło do krwawienia dooskrzelowego zakończonego zgonem chorej. Według naszej wiedzy przedstawiony przypadek jest pierwszym opublikowanym opisem pacjenta z ziarniniakowatością z zapaleniem naczyń oporną na cyklofosfamid, która została powikłana perforacjami oskrzeli i podniebienia.

Słowa kluczowe: rituximab, ziarniniakowatość z zapaleniem naczyń, zapalenie naczyń, ziarniniak Wegenera, immunosupresja, perforacja podniebienia, perforacja oskrzeli

Pneumonol. Alergol. Pol. 2014; 82: 454-457

Address for correspondence: Joanna Kosałka, MD, II Katedra Chorób Wewnętrznych, Klinika Alergii i Immunologii, Uniwersytet Jagielloński, Collegium Medicum, ul. Skawińska 8 ,

31-066 Kraków, Poland, Tel.+48 1243052 66, fax: +48 1243052 03, e-mail: joanna.kosalka@gmail.com

DOI: 10.5603/PiAP.2014.0059

Praca wpłynęła do Redakcji: $1.02 .2014 \mathrm{r}$

Copyright (C) 2014 PTChP

ISSN 0867-7077 


\section{Introduction}

Granulomatosis with polyangiitis (GPA), previously known as Wegener's granulomatosis, is a systemic vasculitis affecting small and medium-size blood vessels involving upper airways, lungs, and kidneys [1-4]. The majority of patients with GPA show the presence of anti-neutrophil cytoplasmic antibodies (ANCA) directed against proteinase 3 (anti-PR3) [3, 5]. If GPA is left untreated, it usually leads to rapid progression and death [5]. Mean survival of untreated patients is 5 months, with more than $90 \%$ of patients dying within 2 years of diagnosis [3, 6]. Conventional treatment comprises cyclophosphamide combined with glucocorticoids, which substantially improves GPA prognosis [3, 7, 8]. However, some patients with GPA are refractory to this treatment [8].

Here we present a case of a patient suffering from GPA refractory to conventional treatment with both hard palate and bronchial perforations, who went into remission after rituximab therapy.

\section{Case}

We describe a case of a 57-year-old woman with a seven-month history of nasal discharge, chest pain, polyneuropathy, arthralgia, hearing loss, and CT-confirmed pansinusitis. She had not taken cocaine in the past, which is one of the most common causes of bone and cartilage destruction of the nose. Granulomatosis with polyangiitis (GPA) was diagnosed based on clinical manifestations and the presence of ANCA (with a serum titre 1:320, confirmed as anti-PR3 194RU/ /mL by ELISA). In addition, bronchial mucosa biopsy showed inflammatory granuloma with necrosis. She was then aggressively treated with monthly i.v. doses (15 mg/kg of body weight) of cyclophosphamide and with i.v. methylprednisolone $(1 \mathrm{mg} / \mathrm{kg})$, followed by oral prednisone with a gradual taper from $40 \mathrm{mg}$ per day, with initial clinical improvement. In the seventh month of treatment (a total of $6.3 \mathrm{~g}$ of cyclophosphamide received) progression of the disease was observed, manifesting as reappearance of chest pain and cough, accompanied by several perforations on the hard palate (Fig. 1A). Bronchoscopy revealed additional perforations of the trachea at the level of the carina (Fig. 2A) and bilaterally in the lobar bronchi. Treatment was changed to pulses of methylprednisolone (500 mg for 3 days, followed by $1 \mathrm{mg} / \mathrm{kg} /$ day) and three weekly doses of rituximab $\left(375 \mathrm{mg} / \mathrm{m}^{2}\right)$ resulting in blood B-cell depletion and disappearance of anti-PR3 antibodies. A few weeks later palatal holes diminished in size (Fig. 1B) and all bronchial perforations disappeared, covered by fibrous tissue (Fig. 2B). In the fourth month after rituximab administration, scarring and substantial obstruction of the right main bronchus developed with atelectasis of the upper and middle lobes of the right lung. The patient was transferred to the thoracic surgery department, where the right main bronchus was re-opened using bronchoscopy. The procedure was complicated by bilateral pneumothorax. On the seventh day after the procedure fatal pulmonary bleeding developed and the patient died.

\section{Discussion}

GPA is a rare disease with an annual incidence ranging from 0.5 to 10 cases per million people $[6,9]$. This form of vasculitis usually manifests in

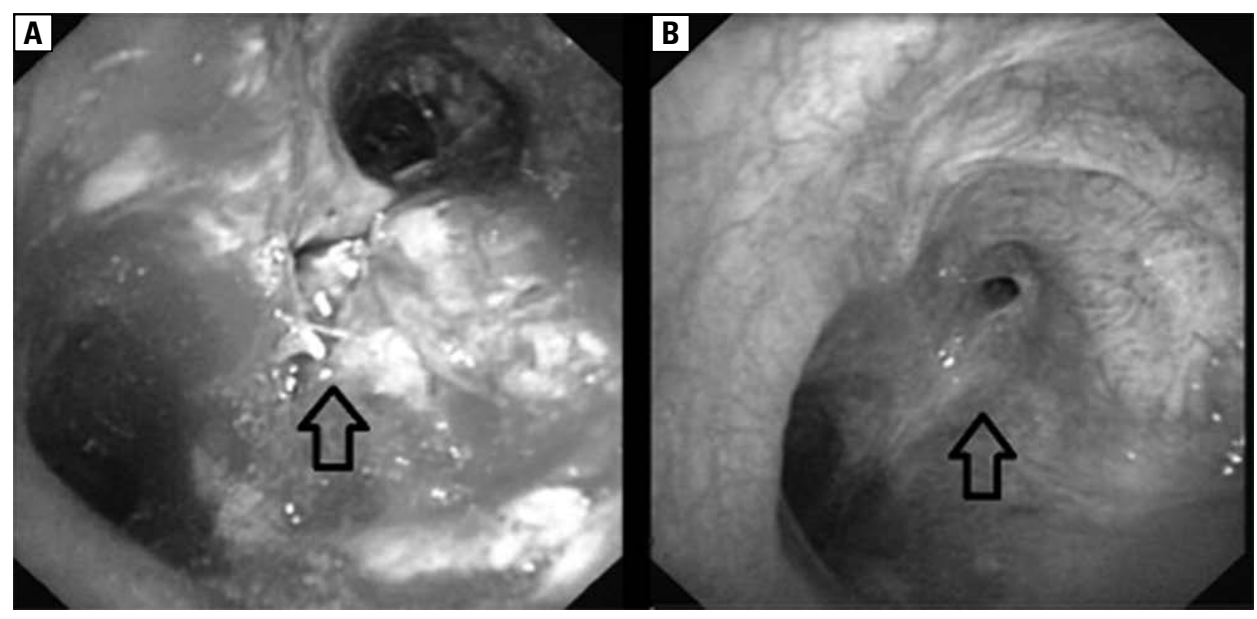

Figure 1. Hard palate holes; A — before rituximab, B — seven weeks after rituximab regimen 


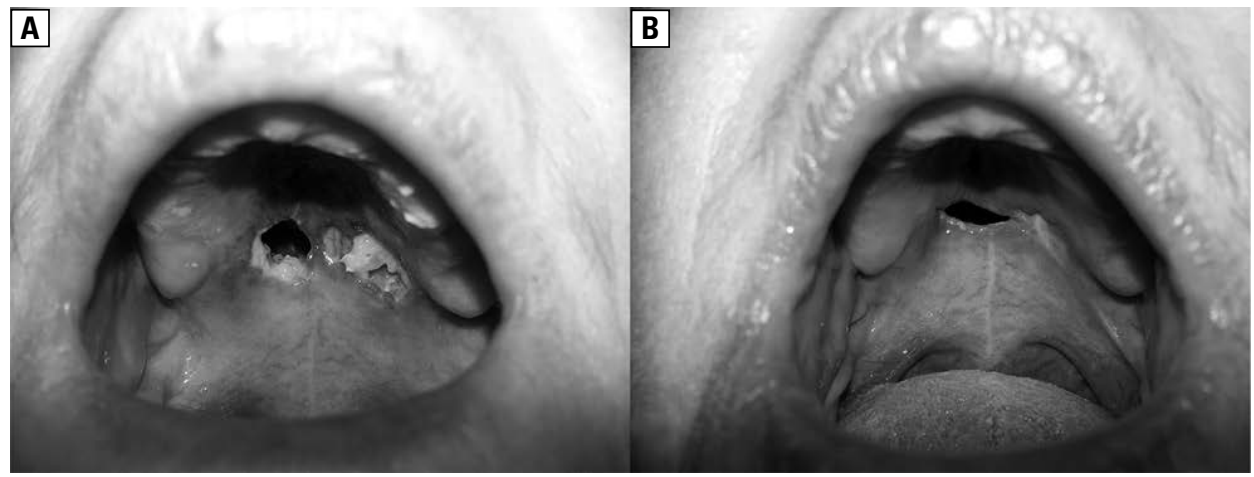

Figure 2. Perforation of the trachea at the level of the carina; A - before rituximab, B - seven weeks after rituximab regimen

the fourth and fifth decades of life, with a male:female ratio ranging from 1:1 to 1.6:1 [3, 10-14]. The course of GPA is variable - from slow to rapid progression leading to life-threatening multiorgan failure, which invariably leads to death [15]. Conventional induction treatment comprises cyclophosphamide combined with glucocorticoids [7]. Unresponsive cases have recently been treated by rituximab [15]. Rituximab, an anti-CD20 monoclonal antibody developed to treat B-cell malignancies, has also been used recently in the treatment of several autoimmune diseases [15-17]. It leads to a rapid depletion of CD20 cells from the circulating blood paralleled by a significant decrease in disease activity observed in the first 6 months in up to $88 \%$ of patients $[3,7,16-21]$. We used rituximab in our patient because of GPA progression despite conventional cyclophosphamide treatment. It manifested with three large hard palate perforations and multiple perforations in the trachea and bronchi. Only a few cases of GPA with palate perforations were reported, and most of these patients were treated with glucocorticoids and cyclophosphamide with temporary benefits [22, 23]. To the best of our knowledge, nobody has previously described GPA with palate perforations associated with tracheal and bronchial perforations, which appeared during standard cyclophosphamide i.v. therapy. Beneficial effects of rituximab in our patient (partial or complete healing) were associated with the disappearance of ANCA from peripheral blood. Preferred regimen of rituximab administration in GPA includes four (500 mg) or two (1000 mg) weekly doses, leading to disease remission in the majority of patients [17]. Maximal effectiveness of rituximab is often observed when anti-CD20 antibody is administered in combination with glucocorticoids [15]. Rituximab B-cells return to peripheral blood 9-12 months after infusion [18].
For this reason, in GPA some physicians suggest additional doses of rituximab every six months [17]. Rituximab is very well tolerated; major infections during the B-cell depletion treatment are uncommon [16]. General experience in treating of GPA patients with respiratory tract perforations is very limited [22, 23]. However, it seems that rituximab might be an option in such patients, especially if they are unresponsive to cyclophosphamide.

\section{Acknowledgement}

The authors would like to thank the Laboratory of Invasive Thoracic Surgery of the II Department of Internal Medicine, Jagiellonian University Medical College, for performing and providing images obtained during bronchoscopies.

\section{Conflict of interest}

The authors declare no conflict of interest.

\section{References:}

1. Pełkowska A., Sancewicz-Pach K., Słowiaczek E., Ogarek I. Diagnostic difficulties in 15-year-old boy with Wegener granulomatosis. Przegl Pediatr. 2005; 35: 74-177.

2. Frosch M., Foell D. Wegener granulomatosis in childhood and adolescence. Eur. J. Pediatr. 2004; 163: 425-434.

3. Cartin-Ceba R., Golbin J.M., Keogh K.A. et al. Rituximab for remission induction and maintenance in refractory granulomatosis with polyangiitis (Wegener's): ten-year experience at a single center. Arthritis Rheum. 2012; 64: 3770-3778.

4. Kucharz E.J., Majdan M., Kotulska A. Ziarniniakowatość z zapaleniem naczyń - nowa nazwa ziarniniakowatości Wegenera i potrzeba jej upowszechnienia. Reumatologia 2012; 50: 541-542.

5. Sneller M.C. Rituximab and Wegener's granulomatosis: are B cells a target in vasculitis treatment? Arthritis Rheum. 2005; 52: 1-5.

6. Takwoingi Y.M., Dempster J.H. Wegener's granulomatosis: an analysis of 33 patients seen over a 10-year period. Clin. Otolaryngol. Allied Sci. 2003; 28: 187-194.

7. Martinez Del Pero M., Chaudhry A., Jones R.B., Sivasothy P., Jani P., Jayne D. B-cell depletion with rituximab for refractory head and neck Wegener's granulomatosis: a cohort study. Clin. Otolaryngol. 2009; 34: 328-335. 
8. Sánchez-Escuredo A., Núñez R., Ibernón M. et al. Rituximab therapy for Wegener's granulomatosis refractory to conventional treatment. Nefrologia 2011; 3: 502-504.

9. Rodrigues C.E., Callado M.R., Nobre CA et al. Wegener's granulomatosis: prevalence of the initial clinical manifestations - report of six cases and review of the literature. Rev. Bras. Reumatol. 2010; 50: 150-164.

10. Akikusa J.D., Schneider R., Harvey E.A. et al. Clinical features and outcome of pediatric Wegener's granulomatosis. Arthritis Rheum. 2007; 57: 837-844.

11. Ziakas N.G., Boboridis K., Gratsonidis A., Hatzistilianou M., Katriou D., Georgiadis N.S. Wegener's granulomatosis of the orbit in a 5-year-old child. Eye 2004; 18: 658-660.

12. Ludwichowska A., Cieszyńska J., Piotrowski S., Kuczkowski J., Gorycki T., Szadejko K. Otological manifestations of Wegener's granulomatosis in 14-year boy — case study. Forum Medycyny Rodzinnej 2012; 6: 175-181

13. Martínez-Morillo M., Grados D., Naranjo-Hans D., Mateo L., Holgado S., Olivé A. Granulomatosis with polyangiitis (Wegener). Description of 15 cases. Reumatol. Clin. 2012; 8: 15-19.

14. Cannady S.B., Batra P.S., Koening C. et al. Sinonasal Wegener granulomatosis: a single-institution experience with 120 cases. Laryngoscope 2009; 119: 757-761.

15. Staines K.S., Higgins B. Recurrence of Wegener's granulomatosis with de novo intraoral presentation treated successfully with rituximab. Oral Surg. Oral Med. Oral Pathol. Oral Radiol. Endod. 2009; 108: 76-80.
16. Onal S., Kazokoglu H., Koc A., Yavuz S. Rituximab for remission induction in a patient with relapsing necrotizing scleritis associated with limited Wegener's granulomatosis. Ocul. Immunol. Inflamm. 2008; 16: 230-232.

17. Smith R.M., Jones R.B., Guerry M.J. et al. Rituximab for remission maintenance in relapsing antineutrophil cytoplasmic antibody - associated vasculis. Arthritis Rheum. 2012; 64: 3760-3769.

18. Specks U., Fervenza F.C., McDonald T.J., Hogan M.C. Response of Wegener's granulomatosis to anti-CD20 chimeric monoclonal antibody therapy. Arthritis Rheum. 2001; 44: 2836-2840.

19. Ibrahim A.S. Re: Rituximab for refractory head and neck Wegener's granulomatosis. Clin. Otolaryngol. 2009; 34: 581-582.

20. Taylor S.R., Salama A.D., Joshi L., Pusey C.D., Lightman S.L. Rituximab is effective in the treatment of refractory ophthalmic Wegener's granulomatosis. Arthritis Rheum. 2009; 60: 1540-1547.

21. Omdal R., Wildhagen K., Hansen T., Gunnarsson R., Kristoffersen G. Anti-CD20 therapy of treatment-resistant Wegener's granulomatosis: favourable but temporary response. Scand J. Rheumatol. 2005; 34: 229-232.

22. Sciascia S., Kuzenko A., Bertero M.T. Medical image. Palatal perforation. Wegener granulomatosis. N Z Med J. 2009; 122: 122-123.

23. Kasifoglu T., Cansu D., Korkmaz C. Clinical images: perforation of the nasal septum and palate due to Wegener's granulomatosis. Arthritis Rheum. 2008; 58: 2564. 